\title{
RETRIBUSI PASAR DAN PENYEDIAAN FASILITAS UNTUK PEDAGANG PASAR DI PASAR TANJUNG JEMBER
}

\author{
Ida Lailatul Musyarrofah ${ }^{1}$, Retna Ngesti Sedyati ${ }^{1}$, Sri Kantun ${ }^{1}$ \\ ${ }^{1}$ Program Studi Pendidikan, Fakultas Keguruan dan Ilmu Pendidikan, Universitas Jember \\ e-mail: retnasedyati.fkip@unej.ac.id
}

\begin{abstract}
Abstrak
Tujuan penelitian ini adalah untuk menggambarkan retribusi pasar dan penyediaan fasilitas pedagang pasar di Pasar Tanjung Kabupaten Jember. Metode penentuan lokasi penelitian menggunakan metode purposive area yaitu Pasar Tanjung, Kecamatan Kaliwates, Kabupaten Jember. Penentuan subjek penelitian dalam penelitian ini menggunakan metode snowball sampling. Metode pengumpulan data yang digunakan terdiri dari: observasi, wawancara, dan dokumentasi. Analisis data yang digunakan adalah reduksi data, penyajian data, dan penarikan kesimpulan (verifikasi). Hasil penelitian menunjukkan bahwa retribusi pasar di Pasar Tanjung bersumber dari penarikan sewa tempat usaha, penarikan retribusi kebersihan dan penarikan parkir. Retribusi pasar setiap tahunnya mengalami penurunan, faktor yang menyebabkan penurunan retribusi pasar adalah kurangnya kesadaran pedagang dalam membayar retribusi. Pemasukan retribusi pasar nantinya akan di laporkan ke Pemerintah Daerah dan pengelolaannya diserahkan sepenuhnya kepada Pemerintah Daerah. Fasilitas yang ada di Pasar Tanjung antara lain: toilet/WC, bank sampah, tempat parkir, gerobak sampah dan musholla.
\end{abstract}

Kata Kunci: Retribusi pasar, fasilitas pedagang, pasar Tanjung

\section{PENDAHULUAN}

Keberhasilan pembangunan daerah sangat tergantung kepada kemampuan keuangan daerah. Daerah dituntut untuk dapat menggali sumber-sumber pendapatan sendiri yang ada dalam daerahnya. Dengan begitu daerah bisa membiayai kebutuhan daerahnya sendiri baik dalam pembiayaan roda pemerintahan maupun pembiayaan pembangunan. Keberhasilan pengelolaan penerimaan daerah tidak semata diukur dari jumlah penerimaan yang dapat dicapai, tetapi sejauh mana pajak daerah dan retribusi daerah dapat berperan mengatur perekonomian masyarakat agar dapat bertumbuh kembang yang pada gilirannya dapat meningkatkan kesejahteraan masyarakat di daerah. Secara teoritis kemampuan keuangan daerah dapat ditingkatkan dengan intensifikasi maupun ekstensifikasi.

Retribusi daerah adalah pungutan daerah sebagai pembayaran atas jasa atau pemberian izin tertentu yang khusus disediakan dan atau diberikan oleh pemerintah daerah untuk kepentingan orang pribadi atau badan. Menurut Marihot P.Siahaan (2005:6) Retribusi daerah adalah pungutan daerah sebagai pembayaran atas jasa atau pemberian izin tertentu yang khusus disediakan dan atau diberikan oleh pemerintah daerah untuk kepentingan orang pribadi atau badan.

Menurut UU No.66 Tahun 2001 jenis-jenis retribusi daerah dapat dikelompokkan menjadi 3 yaitu :

1. Retribusi Jasa Umum

2. Retrubusi Jasa Usaha

3. Retribusi Perizinan Tertentu

Retribusi pasar di Pasar Tanjung masuk dalam kategori Retribusi Jasa Umum yaitu 
retribusi atau jasa yang disediakan atau diberikan oleh pemerintah daerah untuk tujuan kepentingan dan kemanfaatan umum serta dapat dinikmati oleh orang pribadi atau badan. Retribusi pasar masuk dalam retribusi jasa umum karena memberikan manfaat khusus bagi orang pribadi atau badan yang diharuskan membayar retribusi, disamping untuk melayani kepentingan dan kemanfaatan umum. Di Pasar Tanjung Jember masuk dalam retribusi jasa umum karena di Pasar Tanjung melayani kepentingan dan kemanfaatan umum.

Potensi yang dapat digali oleh pemerintah daerah seperti Kabupaten Jember adalah potensi pada sektor pajak. Pajak menjadi salah satu penopang pendapatan terbesar bagi total pendapatan daerah. Semakin tinggi pendapatan yang diperoleh dari sektor pajak maka beban anggaran akan semakin kecil. Dana bagi hasil pajak dan bukan pajak antara pemerintah daerah dan pemerintah pusat menjadi alternatif untuk dapat menggerakkan perekonomian daaerah melalui pengeluaran yang bersifat efektif dan produktif. Selain itu Kabupaten Jember juga menjadikan Retribusi Daerah sebagai sumber keuangan yang paling diandalkan. Retribusi Daerah yang terdiri dari retribusi jasa umum antara lain pelayanan kesehatan dan pelayanan persampahan, jasa usaha (berdagang) dan retribusi perijinan tertentu merupakan sektor yang sangat besar untuk digali dan di perluas pengelolaannya.

Menurut Peraturan Daerah No. 3 Tahun 2001 Retribusi pasar adalah pembayaran atas pelayanan penyediaan fasilitas pasar berupa pelataran dan los yang dikelola oleh pemerintah daerah dan khusus disediakan untuk pedagang. Menurut Sunarto (2005) retribusi pasar adalah pungutan yang dikenakan pada pedagang oleh Pemerintah Daerah sebagai pembayaran atas pemakaian tempat-tempat berupa toko/kios, counter/los, dasaran, dan halaman pasar yang disediakan didalam pasar daerah atau pedagang lain yang berada di sekitar pasar daerah lainnya sampai dengan radius 200 meter dari pasar tersebut. Pemerintah Kabupaten Jember melalui Dinas Pasar Kabupaten Jember selaku dinas yang menjadi unsur pelaksana di bidang pendapatan yang mempunyai tugas dan wewenang dalam menggali sumber-sumber pendapatan asli daerah. Kontribusi Dinas Pasar Kabupaten Jember terhadap pemasukan daerah bersumber dari segi pendapatan sektor retribusi pasar tradisional. Salah satu usaha yang dilakukan oleh Pemerintah Daerah dalam mengelola retribusi Pasar ini adalah memberikan pelayanan kepada masyarakat sesuai dengan apa yang telah mereka bayarkan kepada pemerintah. Keberadaan pelayanan ini dirasakan cukup penting sebagai aspek yang harus dilakukan dalam tatanan demokrasi di daerah itu sendiri. Pelayanan publik sebagai indikator utama bagi Pemerintah Daerah dalam menyelenggarakan pemerintahan harus dilaksanakan sesuai dengan peraturan yang berlaku dan dikelola dengan baik, karena pengelolaan retribusi pasar tidak dapat dilepaskan dari pelayanan yang diberikan.

Di Pasar Tanjung Jember yang merupakan pasar terbesar di Kota Jember masih terdapat permasalahan-permasalahan mengenai kondisi-kondisi fisik maupun non fisik yang membutuhkan penanganan segera dari pemerintah yang tentunya dengan dukungan dari para pedagang yang ada di Pasar Tanjung. Berbagai fasilitas tersedia di Pasar Tanjung Jember, diantaranya air bersih, kamar mandi dan toilet, pengelolaan sampah, dan drainase. Ketersediaan fasilitas tersebut, ternyata masih dinilai belum optimal oleh para pedagang pasar serta pembeli. Selain itu keamanan di Pasar Tanjung Jember juga masih kurang maksimal. Fasilitas yang diberikan juga kurang memadai seperti toilet umum dan tempat untuk berdagang juga sangat 
kurang. Sehingga masyarakat Jember berharap untuk mulai membangun kembali pasar sesuai dengan tujuan awal yaitu menjadi pasar yang indah dan rapi. Penyediaan dan penataan fasilitas pelayanan publik harus memperhatikan fungsi dan skala pelayanannya. Terdapat komponen yang paling berperan dalam peningkatan kondisi pasar yang berkenaan dengan konsep penataannya. Komponen tersebut dapat dipisahkan menjadi 2 kelompok komponen, komponen utama merupakan komponen yang membentuk dan memberikan fungsi pasar, sedangkan komponen pendukung merupakan komponen yang perlu disediakan untuk mendukung aktivitas di dalam pasar. Komponen tersebut antara lain:

Komponen utama, yang meliputi:

1. Bangunan

2. Kios dagang

3. Gang antar kios

4. Jalan utama

Komponen pendukung, yang meliputi:

1. Identitas (papan nama, gapura atau tugu)

2. Papan informasi

3. Toilet

4. Mushola

5. Air bersih

6. Drainase

7. Parkir

8. Pemadam kebakaran

9. Tempat pembuangan sampah

Berdasarkan latar belakang di atas maka rumusan masalah dalam penelitian ini adalah bagaimana retribusi pasar dan penyediaan fasilitas pedagang di Pasar Tanjung Jember. Tujuan penelitian ini adalah mendeskripsikan retribusi pasar dan penyediaan fasilitas bagi pedagang di Pasar Tanjung Jember.

\section{METODE}

Jenis penelitian ini adalah deskriptif kualitatif, untuk menggambarkan tentang retribusi pasar dan fasilitas pedagang yang ada di Pasar Tanjung. Metode penentuan lokasi penelitian menggunakan metode purposive area yaitu di Pasar Tanjung, Kecamatan Kaliwates, Kabupaten Jember. Penentuan responden dalam penelitian ini menggunakan metode snowball sampling. Subjek penelitian di Pasar Tanjung yaitu, satu mantri pasar dan 4 pedagang yang berjualan di Pasar Tanjung. Metode pengumpulan data yang digunakan terdiri dari metode: observasi, wawancara, dan dokumen. Analisis data yang digunakan adalah reduksi, penyajian data dan penarikan kesimpulan. 


\section{HASIL DAN PEMBAHASAN}

\section{Data Utama Retribusi Pasar Tanjung Tahun 2011-2015}

Retribusi Pasar Tanjung merupakan jumlah keseluruhan dari pemasukan retribusi yang di dapat dari penarikan pajak yang ada di Pasar Tanjung dari penerimaan sewa tempat usaha dan retribusi persampahan/kebersihan. Selain itu tarif toilet yang ada di Pasar Tanjung juga masuk dalam pendapatan retribusi pasar. Jumlah retribusi yang digunakan dalam penelitian ini dilaporkan setiap tahunnya. Dibawah ini adalah jumlah retribusi di Pasar Tanjung Jember setiap tahunnya selama 5 tahun disajikan pada tabel berikut:

Tabel 1. Pencapaian Target Retribusi Pasar Tanjung Periode 2011-2015

\begin{tabular}{|l|l|l|l|l|}
\hline No & Tahun & Target $(\mathbf{R p )}$ & Realisasi $($ Rp) & Ketercapaian \\
\hline 1 & 2011 & $1.136 .410 .000,00$ & $1.138 .026 .540,00$ & Tercapai \\
\hline 2 & 2012 & $1.143 .100 .000,00$ & $1.134 .598 .450,00$ & Tidak Tercapai \\
\hline 3 & 2013 & $1.170 .805 .000,00$ & $1.032 .607 .340,00$ & Tidak Tercapai \\
\hline 4 & 2014 & $1.206 .800 .000,00$ & $1.005 .692 .400,00$ & Tidak Tercapai \\
\hline 5 & 2015 & $1.223 .405 .000,00$ & $1.006 .746 .200,00$ & Tidak Tercapai \\
\hline
\end{tabular}

Sumber: Dinas Pasar Kabupaten Jember Tahun 2015

Dilihat dari tabel diatas dapat disimpulkan bahwa pencapaian terget retribusi di Pasar Tanjung dari tahun 2012-2015 tidak tercapai. Retribusi pasar setiap tahunnya mengalami penurunan. Pendapatan retribusi pasar setiap tahunnya tidak memenuhi target sesuai yang telah ditentukan oleh Pemerintah Daerah.

2. Data Realisasi Pendapatan Retribusi Pasar Dari Sewa Tempat Usaha Tahun 2016

Data realisasi pendapatan retribusi pasar di dapat dari pemasukan sewa tempat usaha yang ditarik dari para pedagang baik yang mempunyai kios, los maupun pedagang yang ada di pelataran pasar.

Tabel 2. Pendapatan Retribusi Pasar Dari Sewa Tempat Usaha dan Kebersihan Tahun 2016

\begin{tabular}{|c|l|l|}
\hline No & Bulan & Jumlah Pendapatan \\
\hline 1 & Januari & Rp. 82.110.020,00 \\
\hline 2 & Pebruari & Rp. 88.273.630,00 \\
\hline 3 & Maret & Rp. 97.732.140,00 \\
\hline 4 & April & Rp. 89.152.237,00 \\
\hline 5 & Mei & Rp. 91.993.903,00 \\
\hline 6 & Juni & Rp. 95.163.204,00 \\
\hline 7 & Juli & Rp. 80.062.799,00 \\
\hline 8 & Agustus & Rp. 109.715.178,00 \\
\hline 9 & September & Rp. 97.201.590,00 \\
\hline 10 & Oktober & Rp. 95.992.699,00 \\
\hline 11 & November & Rp. 92.653.292,00 \\
\hline 12 & Desember & Rp. 81.296.058,00 \\
\hline
\end{tabular}

Sumber: Dokumentasi Dinas Pasar Tanjung Tahun 2016 
Berdasarkan tabel diatas dapat dilihat pendapatan retribusi pasar dari sewa tempat usaha tahun 2016 mengalami kenaikan dan penurunan. Kenaikan maupun penurunan yang terjadi dari bulan Januari sampai Desember disebabkan oleh banyaknya maupun sepinya pembeli karena jika pembeli sepi para pedagang di los dan pelataran tidak akan membayar pajak sewa tempat usaha di Pasar tanjung. Untuk pedagang yang berjualan los dan pelataran tidak dikenakan sanksi meskipun tidak membayar sewa tempat. Sedangkan pedagang yang mempunyai kios apabila tidak membayar sewa tempat akan dikenakan denda sebesar $2 \%$ dari besarnya penarikan sewa tempat yang dikenakan, apabila selama tiga bulan berturut-turut tetap tidak membayar maka pedagang tersebut akan dicabut ijin sewa tempatnya. Semua pemasukan sewa tempat usaha yang diperoleh nantinya akan disetor ke kas daerah dan pengelolaanya diserahkan sepenuhnya ke pemerintah daerah.

\section{Data Realisasi Retribusi Pasar Dari Pendapatan Parkir Tahun 2016}

Data retribusi pasar dari pendapatan parkir diperoleh dari pemasukan parkir setiap harinya. Parkir di Pasar Tanjung didapat dari penarikan yang dikenakan kepada pengunjung yang menggunakan fasilitas parkir. Adapun data pendapatan parkir, yaitu :

Tabel 3. Jumlah Pendapatan Parkir Tahun 2016

\begin{tabular}{|c|l|l|}
\hline No & Bulan & Jumlah Pendapatan Parkir \\
\hline 1 & Januari & Rp. $12.670 .000,00$ \\
\hline 2 & Pebruari & Rp. 23.990.000,00 \\
\hline 3 & Maret & Rp. $36.845 .000,00$ \\
\hline 4 & April & Rp. $50.030 .000,00$ \\
\hline 5 & Mei & Rp. 62.745.000,00 \\
\hline 6 & Juni & Rp. 65.830.000,00 \\
\hline 7 & Juli & Rp. 40.200.000,00 \\
\hline 8 & Agustus & Rp. 63.745.000,00 \\
\hline 9 & September & Rp. 67.700.000,00 \\
\hline 10 & Oktober & Rp. 69.650.000,00 \\
\hline 11 & November & Rp. 50.200.000,00 \\
\hline 12 & Desember & Rp. 50.185.000,00 \\
\hline \multicolumn{2}{|l|}{ Sumber: Dokumentasi Dinas Pasar Tanjung Tahun 2016 } \\
\multicolumn{2}{|l}{}
\end{tabular}

Dilihat dari tabel diatas jumlah pendapatan parkir tahun 2016 mengalami naik turun. Kenaikan maupun penururan yang terjadi pada tahun 2016 tergantung dari jumlah pengunjung di Pasar Tanjung setiap harinya. Semua pendapatan parkir akan dilaporkan ke kas daerah dan pengelolaannya juga diserahkan sepenuhnya kepada pemerintah pusat.

\section{Fasilitas Yang Ada Di Pasar Tanjung Tahun 2016}

Penarikan retribusi di Pasar Tanjung digunakan untuk kepentingan yang ada di Pasar Tanjung salah satunya adalah pembangunan, selain itu retribusi digunakan untuk perbaikan fasilitas maupun pengadaan fasilitas yang ada di Pasar Tanjung. Adapun fasilitas-fasilitas yang ada di Pasar Tanjung tahun 2016 yaitu : 
Tabel 4. Jumlah Fasilitas di Pasar Tanjung Tahun 2016

\begin{tabular}{|c|l|c|}
\hline No & \multicolumn{1}{|c|}{ Fasilitas } & Jumlah \\
\hline 1 & Toilet/WC & 6 \\
\hline 2 & Bank Sampah & 2 \\
\hline 3 & Tempat Parkir & 4 \\
\hline 4 & Gerobak Sampah & 3 \\
\hline 5 & Musholla & 2 \\
\hline JUMLAH & $\mathbf{1 5}$ \\
\hline
\end{tabular}

Fasilitas yang ada di Pasar Tanjung memerlukan perbaikan maupun penambahan ini ditujukan agar para pedagang merasa nyaman dalam melaksanakan aktivitasnya. Selain itu pembeli juga merasa nyaman mengunjungi Pasar Tanjung.

\section{Fasilitas Yang Ada Di Pasar Tanjung Tahun 2017}

Tabel 5. Jumlah Fasilitas di Pasar Tanjung Tahun 2017

\begin{tabular}{|c|l|c|}
\hline No & \multicolumn{1}{|c|}{ Fasilitas } & Jumlah \\
\hline 1 & Toilet/WC & 6 \\
\hline 2 & Bank Sampah & 2 \\
\hline 3 & Tempat Parkir & 4 \\
\hline 4 & Gerobak Sampah & 3 \\
\hline 5 & Musholla & 2 \\
\hline 6 & Toilet/WC khusus Lansia & 2 \\
\hline JUMLAH & $\mathbf{1 7}$ \\
\hline
\end{tabular}

Sumber: Dokumentasi Dinas Pasar Tanjung Tahun 2017

Fasilitas di Pasar Tanjung dari tahun ke tahun tidak ada penambahan hanya ada perbaikan saja, tetapi pada tahun 2017 ada penambahan fasilitas yaitu penambahan toilet/WC khusus lansia. Toilet/WC tersebut berjumlah dua, dimana satu untuk perempuan satu untuk laki-laki. Letak toilet/WC khusus lansia berada di dekat kantor dinas pasar sebelah selatan di lantai bawah di dekat tangga. Dari tahun 2000 sampai 2016 tidak ada penambahan fasilitas dan hanya ada penambahan di awal tahun 2017.

\section{Pembahasan}

Mengacu dari hasil penelitian diatas, maka peneliti akan membahas tentang retribusi pasar dan fasilitas pedagang di Pasar Tanjung Kabupaten Jember. Retribusi pasar setiap tahunnya mengalami penurunan. Faktor yang menyebabkan penurunan retribusi adalah minimnya pengetahuan para pedagang tentang pentingnya retribusi. Sehingga banyak pedagang yang tidak tepat waktu dalam membayar retribusi pasar. Para pedagang tidak mengetahui bahwa dengan membayar retribusi nantinya akan kembali kepada pedagang itu sendiri dengan adanya perbaikan fasilitas maupun penambahan fasilitas. Pemasukan retribusi pasar nantinya akan di serahkan kepada pemerintah daerah sehingga pengelolaannya 
diserahkan sepenuhnya kepada pemerintah daerah.

Fasilitas yang ada di Pasar Tanjung tidak lepas dari peran retribusi pasar yang di dapat baik dari para pedagang. Pendapatan retribusi pasar di Pasar Tanjung berasal dari penarikan sewa tempat, penarikan pelayanan parkir maupun pelayanan persampahan/kebersihan. Dengan adanya retribusi pasar tentunya harus dimbangi dengan peningkatan pelayanan serta penyediaan fasilitas yang ada di Pasar Tanjung Jember. Namun pada kenyataannya, pengelolaan retribusi pasar selama ini belum sepenuhnya dirasakan oleh para pedagang. Di Pasar Tanjung Jember masih banyak permasalahan-permasalahan mengenai kondisi-kondisi fisik maupun non fisik yang membutuhkan penanganan segera dari pemerintah yang tentunya dengan dukungan dari para pedagang yang ada di Pasar Tanjung.

Di Pasar Tanjung Jember terdapat fasilitas diantaranya, air bersih, kamar mandi dan toilet, pengelolaan sampah, dan drainase. Ketersediaan fasilitas tersebut, ternyata masih dinilai belum optimal oleh para pedagang pasar. Kondisi-kondisi yang ada di Pasar Tanjung saat ini misalnya masih kurangnya frekuensi penyapuan/pembersihan sampah, kurangnya saluran pembuangan sampah, kurang bersihnya toilet yang ada. Selain itu keamanan yang kurang terjaga, misalkan sering terjadi pengunjung yang kehilangan helm.

Gambaran mengenai permasalahan kondisi kebersihan Pasar Tanjung dapat dilihat dari kurang memadainya sarana sanitasi berupa kurangnya tempat sampah untuk menjaga kebersihan pasar, kondisi atap pasar yang banyak terdapat pasir dan banyak atap yang bocor, drainase yang kurang memadai dan tidak ditutup sehingga sering tersumbat kotoran yang masuk ke dalam drainase dan menyumbat aliran air limbah. Berdasarkan kondisi-kondisi ini maka dapat dilihat bahwa pasar dalam masalah kebersihan kurang maksimal serta keamanan yang kurang sehingga membuat para pedagang merasa kurang nyaman. Berikut pernyataan dari salah satu pedagang yang ada di Pasar Tanjung Jember:

“...Dari segi keamanan dan kebersihan di pasar tanjung masih kurang memadai, salah satunya sering terjadinya pencurian di lapak lapak pedagang dan kebersihan hanya di bersikan satu kali sehari serta kurangnya penyediaan tempat sampah”. Selain toilet yang ada di Pasar Tanjung masih minim dan kebersihannya masih sangat kurang”. (SW:2017)

Fasilitas yang diberikan juga kurang memadai seperti toilet umum dan tempat untuk berdagang juga sangat kurang sehingga masih banyak penjual sayur atau buah-buahan yang berjualan di pinggir pasar atau di pinggiran tangga. Ditambah lagi keadaan bangunan yang sudah tua, atap yang bocor, banyaknya ruangan yang tidak dipakai yang seharusnya masih bisa di manfaatkan oleh pengelola namun terabaikan begitu saja karena sudah rusak. Dan juga batas dinding pada lantai dua Pasar Tanjung ini sudah rusak sehingga dapat mengganggu penjual atau pembeli yang berada disana. Berikut pernyataan dari salah satu pedagang yang berjualan di tangga pasar:

“...saya berjualan di Pasar Tanjung sudah lama lebih dari 10 tahun, dari dulu saya berjualan di tangga karena tidak mempunyai tempat berjualan. Saya juga ikut membayar uang iuran tiap hari meskipun tidak mempunyai tempat. Ya bagaimana lagi daripada tidak berjualan, tetapi saya berharap pemerintah bisa melihat nasib saya 
sehingga saya bisa mempunyai tempat berjualan yang layak dan saya bisa berjualan dengan nyaman”. (HH:2017)

Pasar Tanjung masih jauh dari kata baik karena masih banyak fasilitas yang perlu dibenahi maupun di tambah. Bangunan di Pasar Tanjung masih jauh dari kata layak karena dilihat dari faktor bangunan, banyak bangunan di Pasar Tanjung yng sudah tua dan rapuh. Pasar Tanjung masih memerlukan pembenahan agar Pasar Tanjung menjadi pasar yang layak, bersih dan nyaman. Semua permasalahan di Pasar Tanjung dapat diatasi tetapi tidak lepas dari peran para pedagang dalam membayar retribusi. Apabila para pedagang lancar dalam membayar retribusi tidak sembunyi-sembunyi pastinya pemasukan retribusi akan meningkat dan bisa digunakan untuk perbaikan dan penambahan fasilitas.

\section{PENUTUP}

Berdasarkan hasil penelitian dan pengamatan secara langsung terhadap subjek penelitian ditemukan fakta, bahwa di Pasar Tanjung pendapatan retribusi mengalami penurunan setiap tahunnya. Faktor yang menyebabkan penurunan retribusi di Pasar Tanjung disebabkan kurangnya kesadaran pedagang dalam membayar retribusi pasar. Dari segi fasilitas masih kurang memadai karena banyak sekali fasilitas yang tidak memenuhi standar sebagai pasar yang baik dan bersih.

Selain itu kesadaran dari para pedagang maupun pembeli masih sangat minim, yaitu rendahnya tingkat kesadaran pedagang dalam berpartisipasi menjaga kebersihan lingkungan di Pasar Tanjung, rendahnya kepedulian masyarakat terhadap Pasar Tanjung dan kurangnya peran pedagang Pasar Tanjung dalam upaya menjaga sarana dan prasarana di Pasar Tanjung.

Berdasarkan kesimpulan di atas, maka dapat diberikan saran pada beberapa pihak yaitu:

1. Pemerintah diharapkan dapat memperbaiki kekurangan-kekurangan yang ada di Pasar Tanjung agar fasilitas yang ada di Pasar Tanjung dapat diperbaiki sehingga para pedagang dapat berjualan dengan nyaman.

2. Pedagang yang berjualan di Pasar Tanjung diharap bisa menjaga fasilitas yang ada di Pasar Tanjung, selain itu kebersihan juga harus dijaga sehingga Pasar terlihat bersih, rapi dan nyaman baik untuk pedagang maupun pembeli.

\section{DAFTAR PUSTAKA}

Peraturan Pemerintah No.66 Tahun 2001 tentang Pelayanan Pasar.

Peraturan Pemerintah No.3 Tahun 2001 tentang Retribusi Pasar.

Mariot P. Siahaan. 2005. Pajak Daerah dan Retribusi Daerah. Jakarta: PT. Rajagrafindo Persada.

Sunarto. 2005. Pajak dan Retribusi Daerah. Yogyakarta: Penerbit Amus dan Citra Pustaka.

http://www.landasanteori.com/2015/07/pengertian-retribusi-daerah-makalah-dan.html. (Diakses pada 21 Desember 2016).

http://padyangantaxcenter.blogspot.co.id/2013/05/pengertian-retribusi-pasar.html. (Diakses pada 21 Desember 2016). 